\title{
Organic geochemical perspectives on estuarine processes: sorption reactions and consequences
}

\author{
John I. Hedges * , Richard G. Keil \\ School of Oceanography, Box 357940, University of Washington, Seattle, WA 98195-7940, USA
}

Received 4 November 1998; accepted 8 December 1998

\begin{abstract}
The conventional paradigm for conceptualizing the behavior of bioactive materials in estuarine systems has been to think of dissolved and particulate organic matter as separate entities that do not readily interconvert or associate with minerals. However, many organic molecules are extensively, and to some extent reversibly, associated with mineral surfaces in rivers and estuaries. The realization that some organic molecules may actively partition between dissolved form and the surfaces of minerals has great geochemical implications for many natural environments. This brief review touches on some possible ramifications of organic-mineral interactions for estuaries, using the well-studied Amazon River/Estuary system as an example. (C) 1999 Elsevier Science B.V. All rights reserved.
\end{abstract}

Keywords: estuary; river; organic; geochemistry; sorption; mineral; biodegradation

\section{Introduction}

Estuaries are among the most challenging environments on earth in which to study the origins, pathways and fates of dissolved and particulate materials. The many possible sources and sinks of waterborne substances include river drainage basins, flanking marshes, sediments, the atmosphere and coastal ocean waters. Freshwater discharge and tidal forcing change daily. Turbulent mixing of fresh and salt water can generate abrupt changes in temperature, salinity, turbidity, $\mathrm{pH}$ and bioactive element concentrations. Superimposed on this physical variability are biological processes acting on time scales of seconds to seasons. It is little wonder that the

\footnotetext{
* Corresponding author. Tel.: + 1-206-543-0744; Fax: + 1-206543-0275; E-mail: jihedges@u.washington.edu
}

forms and pathways of materials in transit within estuaries are challenging to delineate, or that processes affecting such diverse and abrupt transformations often remain obscure.

The properties of organic substances are ideally suited for delineating estuarine processes and specific biological and geographic sources. These traits include bulk organic properties (e.g., $\mathrm{C} / \mathrm{N}, \delta^{13} \mathrm{C}$, $\left.\Delta^{14} \mathrm{C}\right)$ that are broadly imprinted and often persistent (e.g., Cifuentes et al., 1988; Fichez et al., 1993; Santschi et al., 1995). Less widely representative, but much more specific and sensitive, are molecular 'biomarkers' that can trace biogenic materials of both terrestrial and marine origin (e.g., Laureillard and Saliot, 1993; Harvey and Johnston, 1995; Canuel et al., 1995). Isotope-ratio-monitoring gas chromatography/mass spectrometry (irm-GC/MS) combines the strengths of molecular and isotopic tracers 
(Schoell and Hayes, 1994; Lichtfouse and Budzinski, 1995), providing source information at a level of detail commensurate with the complexity of estuarine systems. With the advent of compound-specific radiocarbon analyses (Eglinton et al., 1996), the comparative dynamics of individual types of organic molecules can now also be assessed.

Geochemists face many challenges in applying organic molecules as complementary tools to inorganic substances when investigating estuarine processes. One of the greatest tasks is to better understand the mechanisms that partition organic and inorganic substances between minerals and ambient waters, and to determine how these processes affect the estuarine distributions and fates of bioactive elements. There is growing evidence that a major fraction of organic matter carried to estuaries by rivers is tightly associated with the surfaces of suspended minerals (Gibbs, 1973; Hunter and Liss, 1979; Keil et al., 1997a). This observation has profound geochemical implications. For example, organic molecules bound to minerals may dissociate in the sharp chemical gradients of estuaries, thereby changing their mode of transport and bioavailability. Such phase conversions must be taken into account both in tracer applications and in budgets for turbid estuaries where both dissolved and particulate forms of total organic matter must be discriminated and followed. The size of organic molecules in aquatic systems also may be a key control on their composition and reactivity, necessitating means for isolating different size classes across the entire spectrum of dissolved and particulate materials. This review focuses specifically on how organic-mineral interactions may affect the forms, reactions and fates of organic materials and their associated minerals in estuaries and adjacent coastal ocean environments. For broader discussions of the larger questions of the origins and fates of terrestrial organic matter in the ocean see recent reviews by Hedges and Oades (1997) and Hedges et al. (1997).

\section{Forms of organic matter}

The sizes of different organic, inorganic and mixed materials in estuaries predestine those entities toward specific processes and fates. For example, particles larger than about a micron in effective diameter will either float or sink in quiescent water, depending on their relative density. Submicron-size particles are buffeted by Brownian motion of water molecules to the extent that they remain suspended regardless of their density. This fundamental physical difference is largely the basis for the distinction of particulate and dissolved materials by separation on filters with pore sizes of $\sim 1 \mu \mathrm{m}$. 'Dissolved' substances, however, have their own size-based physical propensities. Colloids in the size range of about $1 \mathrm{~nm}-1 \mu \mathrm{m}$ are affected most by surface-based processes such as coagulation, sorption, and light scattering. 'Dissolved' units less than $1 \mathrm{~nm}$ are controlled largely by intermolecular interactions such as van der Waals attractions, and hydrogen or covalent bonding. The general trend with decreasing size is that the physicochemical behavior of organic particles will be affected predominantly by gravitational, then surface heterogeneous, and finally homogeneous chemical processes.

Although geochemists often conceptualize materials in estuarine systems as being discrete minerals, organic debris, ions and molecules; the actual physical forms are typically inorganic/organic mixtures. These 'assemblages' range from aggregates of coarse organic debris and minerals in fecal pellets and flocks, to organic molecules sorbed on mineral surfaces, to metal ions complexed with organic molecules (Hedges and Oades, 1997). Since masses of inorganic materials typically predominate by orders of magnitude over those of organic substances in estuarine waters and sediments, the associated minerals and ions usually control organic distributions. Even when inorganic and organic constituents of waters and sediments are not intimately associated, the mineral matrix imposes physical and chemical constraints (e.g., advection/diffusion rates, reaction centers, and redox regimes) that affect coexisting biochemicals and their reaction products.

One variable that determines the form and fate of organic matter introduced by rivers into estuaries is the concentration of total suspended solids (TSS) in the freshwater input. In general, as TSS concentrations increase, the fraction of total organic carbon (TOC) that is transported in particulate form also increases. This trend is evident, for example, in the Amazon River mainstream and its major tributaries (Fig. 1). Although these very different rivers all 


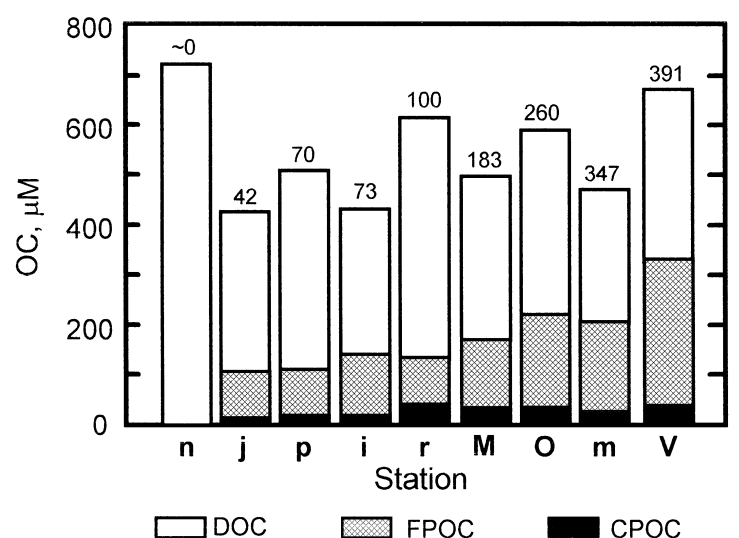

Fig. 1. Concentrations $(\mu \mathrm{M})$ of dissolved (DOC, $<0.5 \mu \mathrm{m})$, fine particulate (FPOC, 0.5-65 $\mu \mathrm{m}$ ) and coarse particulate (CPOC, $>65 \mu \mathrm{m}$ ) organic carbon (OC) in the mainstem and major tributaries of the Brazilian Amazon (from Hedges et al., 1994). Total suspended solids (TSS) concentrations (mg/l) are given above the stacked bars for individual stations, which are listed in order of increasing TSS. River abbreviations: n, Negro; j, Japurà; p, Purús; i, Içà; r, Juruà; m, Madeira; M, O and V, Amazon mainstem at Manacapurú, Òbidos and Vargem Grande, respectively.

contain similar TOC concentrations of $550 \pm 100$ $\mu \mathrm{M}$, the fraction of the total that exists in particulate form ( $>0.5 \mu \mathrm{m}$, diameter) ranges from essentially zero for the blackwater Rio Negro $(\mathrm{TSS} \approx 0)$ to $40-50 \%$ for whitewaters (TSS $\approx 250-400 \mathrm{mg} / \mathrm{l}$ ) of the Amazon mainstream and Rio Madeira (Hedges et al., 1994). Likewise, the ratio of fine $(0.5-65 \mu \mathrm{m})$ particulate organic carbon to DOC increases at greater concentrations of suspended fine particles (Devol and Hedges, in press).

A second pattern seen for the Amazon system, and essentially all rivers (Meybeck, 1982), is that the weight percentage of particulate organic matter (\% POC) decreases with increasing TSS concentration (Fig. 2). Although such plots of A/B vs. B (OC/TSS vs. TSS) all have a boomerang shape (Berges, 1997), the positioning of the resulting curve can still be geochemically informative. At the low extreme of TSS concentrations, the organic-rich suspended particulate material comprises primarily flocculated humic colloids (in blackwater rivers) or plankton (in rivers with relatively transparent water) and their remains (Meybeck, 1982). The precipitous drop in \%POC at low TSS concentrations (1-10 $\mathrm{mg} / \mathrm{l})$ results from initial dilution of low-density organic particles with larger masses of suspended minerals. Dilution by minerals continues up until extremely high turbidities (TSS $>500 \mathrm{mg} / \mathrm{l}$ ), such as in the Madeira (Fig. 2) or Yellow and Yang Tze Rivers (Cauwet and Mackenzie, 1993), where \%POC approaches the intrinsic organic content of the pure suspended minerals. The mineral-associated organic matter may be either sorbed molecules and/or fossil remains within the matrix of particles weathered from sedimentary rocks. In the example of the Amazon River System (Fig. 2), the general shape of the \%POC vs. TSS plot can be explained by simple mixing of discrete organic and mineral-rich particles. The observation, however, that the \%POC values of suspended particle mixtures from more turbid reaches of the mainstream and Madiera River are greater than would be expected for simple dilution of discrete organic particles (Fig. 2), suggests partitioning of organic substances between water and mineral surfaces (later discussion). Partitioning is a critical process to understand because it may largely determine the forms of organic substances discharged to estuaries, and hence their subsequent physical pathways and chemical reactions.

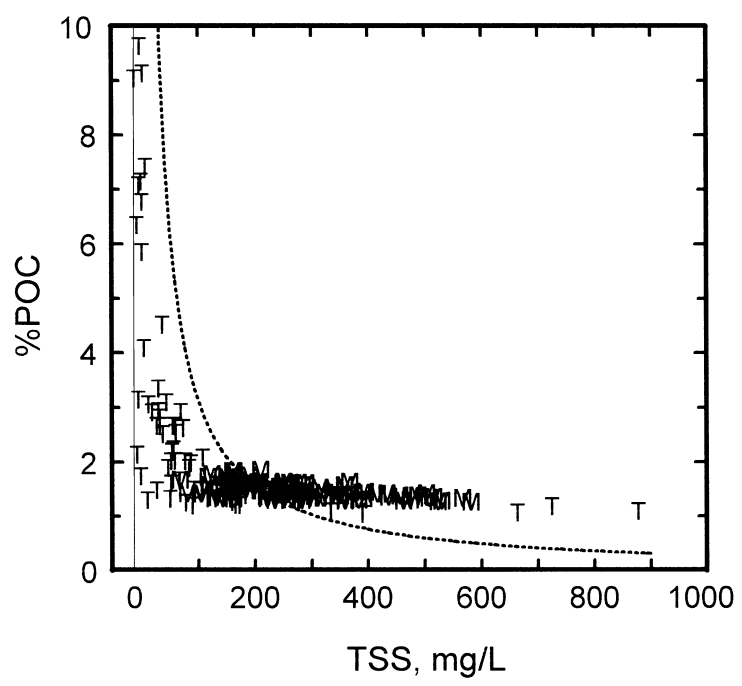

Fig. 2. Weight percent of particulate organic carbon (\%POC) vs. total suspended solids (mg/l) in the Amazon River system (from Devol and Hedges, in press). $\mathrm{T}$ indicates tributaries and $\mathrm{M}$ denotes samples from the mainstem Amazon. The dotted line represents the calculated trend for incremental dilution of $6.50 \mathrm{mg} / 1$ of discrete organic particles $(3.25 \mathrm{mg} / 1$ of POC) by $0-900 \mathrm{mg} / 1$ of organic-free mineral particles. 


\section{Organic/mineral associations}

Important insights into processes affecting organic matter distributions can be obtained by studies of the associations of the mineral and organic components of the suspended particle mixture. For example, hydrodynamically separated size fractions of fine particles $(0.5-65 \mu \mathrm{m})$ suspended in the Amazon mainstream exhibit a direct relationship between \%POC and the specific surface areas (SA) of the mixture (Fig. 3). The slope of the relationship corresponds to an 'organic loading' of $0.5-1.0 \mathrm{mg} \mathrm{OC} / \mathrm{m}^{2}$ surface (Keil et al., 1997a). The same direct relationship, within a similar loading range, has been observed for other major rivers (Keil et al., 1997a), many coastal marine sediments (Mayer, 1994a; Keil et al., 1994a, 1997b), and a number of soils (Mayer, 1994b; Hedges and Oades, 1997). Increasing organic concentrations at the higher surface to mass ratios of smaller particles suggests that most of the organic material is sorbed to mineral surfaces (Mayer, 1994a,b). This inference is supported by the fact that the bulk of the organic material in these samples cannot be separated from the coexisting mineral particles by floating in heavy liquids or other physical means (Keil et al., 1994a). This pattern also is consistent with grow-

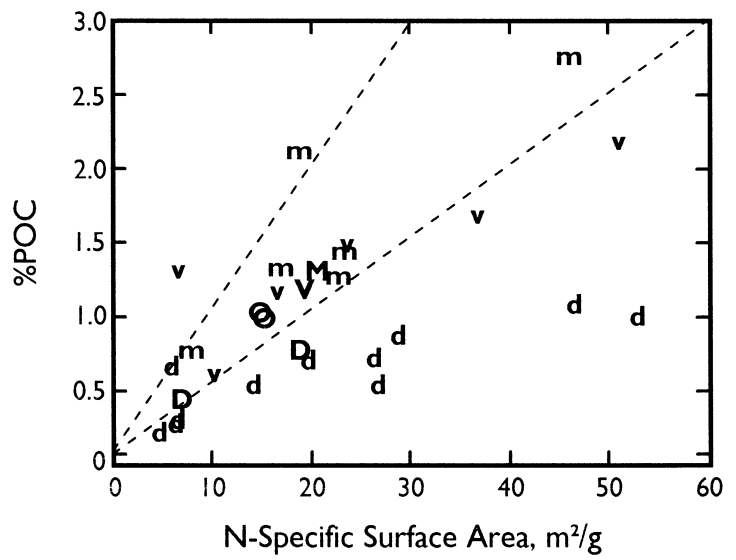

Fig. 3. \%POC vs. specific surface area $\left(\mathrm{m}^{2} / \mathrm{g}\right)$ for suspended particulate material collected from the Amazon mainstream at Vargen Grande (v), Manacapurú (m), and Òbidos (O), Brazil. Lower case letters represent size-fractionated samples, whereas upper case letters indicate bulk sediments. Also shown are corresponding organic loadings for minerals from the Amazon delta (d). The dashed lines represent organic loadings of 0.5 and $1.0 \mathrm{mg}$ OC $/ \mathrm{m}^{2}$ (from Keil et al., 1997a). ing evidence that sorption protects organic matter from microbial remineralization in soils (Nelson et al., 1994) and sediments (Keil et al., 1994b), thereby 'locking in' the shielded loading. Protective partitioning of organic substances between dissolved and sorbed forms also would account for the higher fractions of TOC associated with particles in more turbid river water (e.g., Fig. 1). Because sorption is not extensively reversible on short time scales (Henrichs, 1995), associated organic substances likely represent a long partitioning history between the relative masses and types of minerals and organic molecules characteristically present in the soils, aquifers and streams of the parent river basin.

To understand and predict the fates of dissolved and particulate riverine organic matter in estuaries it is necessary to know how organic-mineral interactions occur within river basins. Rivers typically export about $1 \%$ of the net primary production within their catchments to the ocean (Ludwig et al., 1996). Terrigenous organic matter is initially biosynthesized into particulate form by plants, which in most basins are vasculated and rich in substances such as cellulose, hemicellulose, protein, pectin, cutin, suberin, lignins and tannins (De Leeuw and Largeau, 1993). Since the microorganisms that recycle these biomacromolecules must do so internally, and cannot infuse molecules much greater than $500 \mathrm{Da}$ in mass through their cell walls, at least $99 \%$ of the entire primary production of river basins must be degraded by exoenzymes to structural remnants not much larger than a triose. Because uptake of the structural units released extracellularly by microorganisms is so efficient, most of the remaining $1 \%$ or so of organic matter that escapes into the environment should be highly degraded and at least partially solubilized. This inference is supported by the observation that rivers export most of their organic matter in soluble (Schlesinger and Melack, 1981) or sorbed (Keil et al., 1997a) form, and that both fractions are measurably aged (Hedges et al., 1986b; Trumbore, 1993) and highly degraded vs. their parent biomacromolecules (Hedges et al., 1986a, 1994).

The conventional model of how biomacromolecules are degraded in nature, and a new conceptual model involving sorption, are illustrated in Fig. 4. These models are similar in that both initially involve incremental breakdown of biomacro- 


\section{CONVENTIONAL DIAGENETIC MODEL}

Tissues and

Microorganisms Biopolymers Monomers Condensates Geopolymers
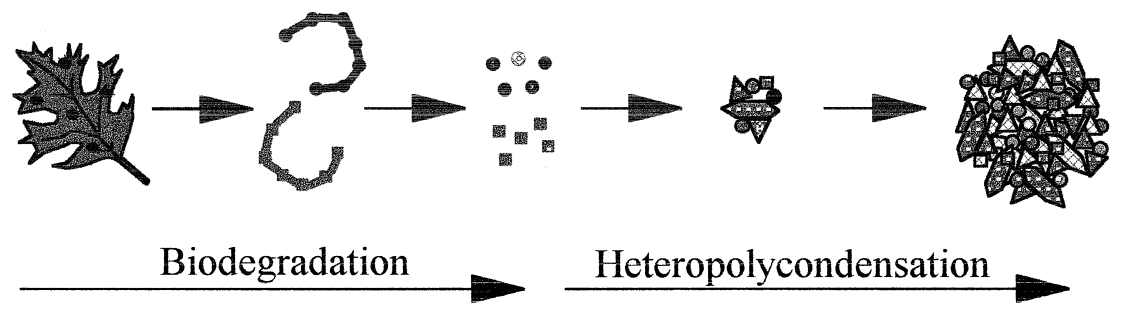

\section{DIAGENETIC MODEL WITH PARTITIONING}

Tissues and Microorganisms Biopolymers Intermediates Monomers Products

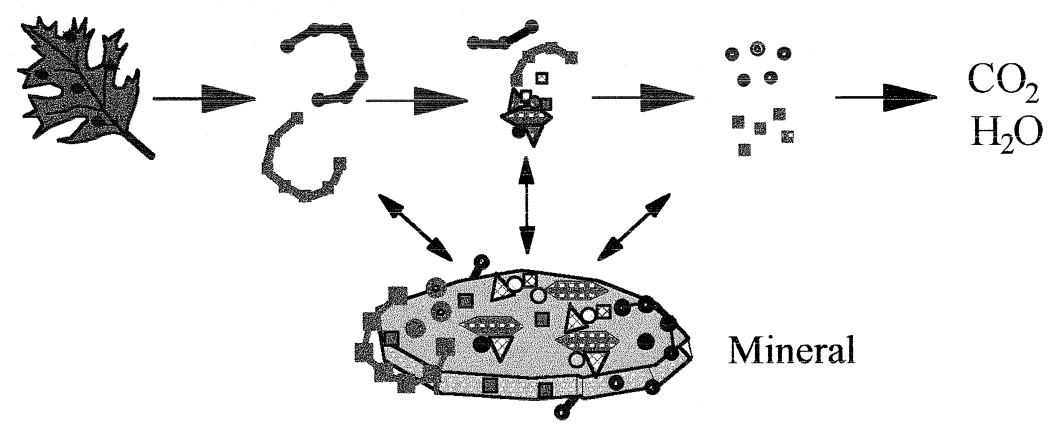

Biodegradation

\section{Partitioning}

Fig. 4. Illustrations of the (top) conventional biodegradation/repolymerization model and (bottom) alternate biodegradation/sorption model.

molecules in different plant and microbial tissues. The resulting decrease in size of the structural units released via 'erosion' of different particulate substrates by microbial exoenzymes, and the attending increases in polarity of the hydrolyzed or oxidized intermediates, leads to increased solubility in water. Most of the dissolved structural units are respired to $\mathrm{CO}_{2}, \mathrm{H}_{2} \mathrm{O}$ and nutrients. The two models vary primarily in the pathways by which a small remnant of degraded organic matter is thought to escape respiration. In the conventional biodegradation/heteropoly- condensation model (Fig. 4, top), small degradation products spontaneously combine to form geopolymers such as humic substances (Hedges, 1988). The concept of abiotic condensation is appealing because it should produce a mix of structurally complex molecules that resist further microbial degradation and are unrecognizable as biochemicals. In the alternate biodegradation/sorption model (Fig. 4, bottom), some degradation intermediates escape microbial uptake and are leached into the soil where they partition between the aqueous phase and the surrounding 
soil mineral surfaces. These organic materials theoretically escape remineralization due to protective sorption-spontaneous condensation reactions are not necessarily involved. Organic substances having a high affinity for mineral surfaces would eventually be exported physically from soils into streams and rivers either by erosion (Hedges et al., 1994) or in association with infiltrating clay colloid (Kaplan et al., 1993). Substances which remain dissolved would be exported more rapidly from the landscape to rivers and estuaries, and may have comparatively little physical protection from biodegradation.

The comparative compositions of coarse particulate, fine particulate and ultrafiltered dissolved organic matter (CPOM, FPOM and UDOM) in the extensively studied Amazon River system (Richey et al., 1990) are consistent with the biodegradation/ partitioning model. The isotopic, elemental, and molecular compositions of all the organic materials borne by the lower Amazon system indicate that angiosperm tree leaves are the predominant ultimate source (Devol and Hedges, in press). CPOM, FPOM and UDOM, however, are compositionally distinct from each other and from their vascular plant sources. CPOM compositionally resembles tree leaves and exhibits a ${ }^{14} \mathrm{C}$ content identical to contemporaneous atmospheric $\mathrm{CO}_{2}$ (Hedges et al., 1986b). Thus, CPOM comprises primarily sparingly degraded tree leaf remains, which have been recently biosynthesized and exported surficially to the river. In contrast, elevated ratios of vanillic acid vs. vanillin among lignin derived phenols (Hedges et al., 1988; Goñi et al., 1993), and correspondingly higher percentage yields of nonprotein amino acids (Fig. 5a), indicate that FPOM and UDOM are increasingly degraded (Hedges et al., 1994). This sequence of alteration (UDOM $>$ FPOM $>$ CPOM) corresponds to the apparent size of the organic components, rather than their 'age'. Because FPOM and UDOM account for about $35 \%$ and $60 \%$ of TOC, respectively, almost all of the organic materials discharged by the Amazon to its estuary are heavily degraded. The potential reactivity of such altered riverine organic matter in estuaries and the coastal ocean might be expected to increase with greater particle size (Amon and Benner, 1996a), but be low overall.

The elemental and molecular compositions of different size fractions in the Amazon River indicate
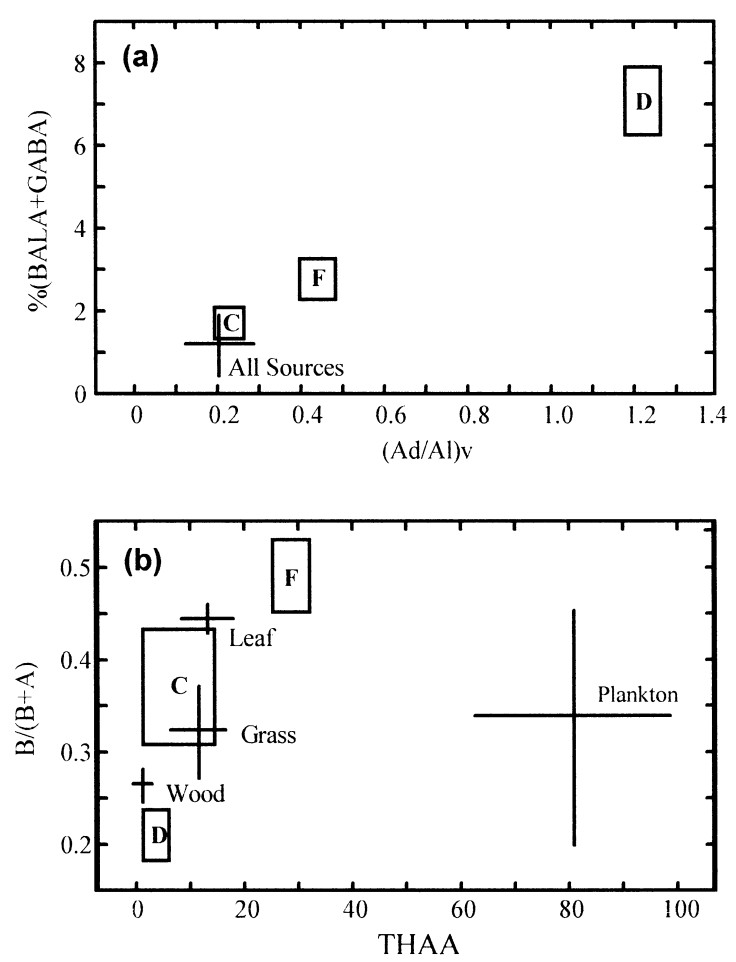

Fig. 5. (a) Combined mole percentages of non-protein amino acids, \%(BALA + GABA), plotted vs. the vanillic acid/vanillin, $(\mathrm{Ad} / \mathrm{Al})_{\mathrm{V}}$, of coarse particulate $(\mathrm{C})$, fine particulate $(\mathrm{F})$ and dissolved (D) organic matter from three sites in the mainstream of the Brazilian Amazon River. Boxes and crosses represent the mean $\pm S$ intervals for riverine organic matter and its fresh potential sources, respectively (see Devol and Hedges, in press, for details). (b) Corresponding fraction of basic amino acid yield normalized to basic-plus-acidic amino acid yield, $\mathrm{B} /(\mathrm{B}+\mathrm{A})$, plotted vs. yield, $\mathrm{mg} / 100 \mathrm{mgOC}$, of total hydrolyzable amino acid (THAA) in different forms of riverine organic matter, and their potential biological sources (after Devol and Hedges, in press).

that selective partitioning of organic substances between mineral surfaces and ambient waters modulates the release of microbially degraded organic substances from the catchment. This second physicochemical process 'overprints' the signature of biodegradation (Fig. 5a) and is particularly sensitive to the nitrogen content of the partitioned organic molecules (Fig. 5b). Unequal distribution of total organic nitrogen is evident from the disparate atomic $\mathrm{N} / \mathrm{C}$ ratios of CPOM (0.30-0.45), FPOM (0.45$0.55)$ and UDOM $(0.20-0.25)$ in the mainstream. This same pattern is repeated at the molecular level (Fig. 5b) where total hydrolyzable amino acids 
(THAA) and even nitrogen-rich basic amino acids also are concentrated preferentially in fine particulate, vs. dissolved, form. Preferential sorption of such nitrogenous organic substances to mineral grains is a well known phenomenon, resulting from attraction between positively charged ammonium functional groups and negatively charged minerals (Theng, 1979; Hedges and Keil, 1995). Thus, solubilized degradation products of plant debris compositionally resembling CPOM appear to be 'disproportionated' (Fig. 5b), with nitrogen-rich substances preferentially retained on soil minerals and eventually exported as FPOM. The nitrogen-poor, hydrophilic counterparts are released as DOM (Hedges et al., 1994). This sorptive mechanism helps immobilize precious fixed nitrogen in drainage basins and also should minimize loss from estuaries, which can be efficient traps for discharged riverine particles (Berner, 1989).

Although already heavily degraded, FPOM discharged by the Amazon and other rivers is extensively lost in the estuary/delta region. Mass balances of FPOM input vs. accumulation in sediments of the adjacent Amazon shelf (Showers and Angle, 1986), and the low ${ }^{13} \mathrm{C} /{ }^{12} \mathrm{C}$ of DIC in porewaters of these sediments (Aller et al., 1996), both indicate that over half of the discharged particulate organic material is lost. In addition, fine minerals accumulating in the Amazon delta carry about half the organic loading they did in the Amazon River, with only about two-thirds of that total being terrigenous (Fig. 3). Similarly, large ( $>60 \%)$ overall losses of terrigenous organic matter are seen in estuaries and deltas of other rivers (Keil et al., 1997a) and are consistent with global evidence for profound recycling of riverine POM (Hedges, 1992). Estuaries, and adjacent coastal zones, may thus operate more heterotrophically than might be inferred from the low substrate quality of the discharged POM, and hence be a greater net source of nutrients and $\mathrm{CO}_{2}$ than would be evident from analysis of the discharged freshwater (Smith and Mackenzie, 1987; Mayer et al., 1998).

Comparison of the large discharges and unique compositions of riverine DOM with the slow cycling rate and distinctly different makeup of the seawater counterpart indicates that most DOM discharged by rivers must also be remineralized rapidly somewhere in the coastal ocean (Hedges et al., 1997). The extent to which DOM loss occurs in estuaries is, however, variable. An average of $\sim 20 \%$ of riverine DOC is estimated to be removed in estuaries, with a range of values of $4-60 \%$ (Fox, 1991). In the detailed study of the Severn estuary, however, DOC was found to behave almost conservatively, even in the presence of large concentrations of resuspended sediments (Mantoura and Woodward, 1983). In addition, studies of the behavior of riverine DOM in open coastal regions have not conclusively demonstrated losses that could be correlated with differences in salinity or other environmental variables (e.g., Moran et al., 1991; Santschi et al., 1995). Evidently, local variations in estuary dynamics and the amounts and compositions of discharged riverine organic matter are critical. To better systematize and predict this variability, it will be necessary to understand the fundamental processes controlling associations of organic molecules with mineral surfaces in rivers, estuaries and the coastal ocean.

\section{Implications of sorptive associations}

Sorption of organic materials to minerals has several major implications for estuarine processes. Conceptually, one of the most important ramifications is that dissolved and particulate organic materials must be studied together with minerals in estuarine systems. Thus, organic matter and nutrient budgets should consider the possible interconversions of organic molecules between dissolved and particulate forms. Although not all organic materials are reversibly sorbed with fast kinetics (Henrichs, 1995), a subset of the total organic pool may be actively distributing in a specific 'exchange window' set by the ambient mass ratio of water to mineral and the minimal partition coefficient $\left(K_{\mathrm{D}}\right)$ of the available organic mixture (Thimsen and Keil, 1998). Organic matter with affinities for mineral surfaces higher than that of the exchange window will not yet have actively exchanged, whereas less surface-active organic materials will already have been desorbed and washed from the system. Partitioning may thus have both a historic aspect, expressed largely by high- $K_{\mathrm{D}}$ components, and an active component, characteristic of the remaining lower- $K_{\mathrm{D}}$ molecules that serve to buffer ambient DOC concentrations. A corresponding 'kinetic window' may also exist in which changes 
in mineral association are only observed if the periodicity of sampling happens to correspond closely to the characteristic rate of the environmental reaction (Middelburg, 1989).

Under these circumstances, any change in the local system ratio of mineral surface area to water mass will result in a repartitioning of organic substances of similar $K_{\mathrm{D}}$. (Thimsen and Keil, 1998; Schwarzenbach et al., 1993). Therefore, organic substances may desorb from surfaces as particles are resuspended from the estuary floor and dispersed, or sorb as sediments accumulate and compact. Formation (or dissolution) of mineral surfaces in estuaries, as a response to ionic (e.g., Michalopoulos and Aller, 1995) or redox changes (Skoog et al., 1996), also can be expected to mobilize organic molecules. Molecules released from dissolving surfaces might in particular exhibit a strong tendency to readsorb. Surface-related processes should be most typical of fine-grained sediments, which have high surface to mass ratios and are less likely than sands to include a major portion of TOC in the form of discrete plant debris (Keil et al., 1994a, 1998).

A second related implication is that the behavior of dissolved and particulate organic materials in estuaries may be predictable in part from the partitioning characteristics of the river and basins from which they came. For example, the high concentrations of DOC typical of blackwater rivers are often attributed to locally abundant wetlands (Schlesinger and Melack, 1981) or coarse sands (Nelson et al., 1993) in the catchment. A related characteristic of these rivers, however, is that the transported organic matter has a history of minimal exposure to mineral surfaces, which may be as rare in the basin as in the river. Organic assemblages with such limited partitioning histories might be expected to include a substantial fraction of sparingly soluble, nitrogen-rich molecules with high $K_{\mathrm{D}}$ values. This notion is supported by the elevated ratios of relatively hydrophobic humic acids vs. fulvic acids in blackwater rivers (e.g., Ertel et al., 1986) and the tendency of these organic materials to flocculate and sink out spontaneously. Although UDOM from the Rio Negro is no more nitrogen-rich than UDOM from Amazon whitewater rivers (Hedges et al., 1994), it is not clear whether this lack of contrast refutes nitrogen-selective sorption, or reflects unusually effective nitrogen retention in the highly weathered catchment. When DOM from blackwater rivers first contacts suspended particles in estuaries, especially under the flocculating influence of sea salts, extensive sorptive uptake might be expected relative to that exhibited by DOM from turbid rivers. Selective removal of humic acids has been reported below the confluence of the Rio Negro with the mainstem Amazon (Ertel et al., 1986), and within numerous estuaries (Fox, 1991).

Finally, assessments of the pathways and reactions of organic materials in estuaries should take their physical forms into account, as well as their biochemical composition. For example, organic molecules sorbed to the surfaces of relatively dense minerals will follow different transport pathways and experience contrasting chemical environments than they would in dissolved form. Organic molecules associated with dense mineral grains transported near the river bed are more likely to experience physical sorting and oscillating redox conditions, but will be less exposed to photochemical reactions (Mopper et al., 1991; Amon and Benner, 1996b). Photoprotective sorption should be particularly true of the colored humic fraction, which in addition to being relative susceptible to photolysis (Kieber et al., 1990), is also hydrophobic and readily sorbed (Ertel et al., 1986). In spite of growing evidence that organic molecules associated with minerals in rivers and coastal marine sediments resist microbial degradation, the example of the Amazon delta (Fig. 3) demonstrates that even highly degraded organic substances can be efficiently desorbed, and remineralized (see also Aller et al., 1996). The observation that a fraction of this original terrestrial loading is replaced in estuaries and deltas by recently formed marine substances suggests that the carrier particle may undergo severe transitions in aqueous chemistry, surface characteristics or microbiology; after which protective sorption is again feasible. The intertwined reactions of organic substances with mineral surfaces and microorganisms are classic examples of biogeochemical processes whose understanding will require balanced attacks across wide disciplinary fronts.

By determining the forms, pathways and availability of organic matter, sorption reactions play a critical role in 'valving' the transfer of terrigenous 
material through estuaries and deltas into the ocean. In particular, molecule-mineral associations may control the fractions of the riverine organic matter that are either buried intact or remineralized along continental margins (Hedges and Keil, 1995). This delicate balance between organic preservation and destruction is critical because only in the latter case are nutrients released to the open ocean where they can support multiple cycles of biological productivity and growth (Broecker and Peng, 1982). Over millions of years, such modulation of terrigenous inputs can have immense effects on the global cycles of carbon and other bioactive elements (Berner, 1989). The old adage that chemical reactions actively occur at interfaces still holds, both for the surfaces of organic-coated mineral particles, and for estuaries where these particles and their entrained organic molecules meet the sea.

\section{Acknowledgements}

We acknowledge Anthony Aufdenkampe and Peter Hernes who provided constructive comments on earlier drafts of this paper, and Al Devol, Ron Benner and Jeff Richey for sharing data and insights in many of the cited studies. We thank Bjørn Sundby for an invitation to present this paper at the 5th International Symposium on Model Estuaries, and for encouragement to contribute an overview paper. This is manuscript 2182 from the School of Oceanography and CAMREX publication 91. This research was funded in part by US NSF grants OCE-9401903 and DEB-9408676 to JH and OCE9402081 to RK.

\section{References}

Aller, R.C., Blair, N.E., Xai, Q., Rude, P.D., 1996. Remineralization rates, recycling, and storage of carbon in Amazon shelf sediments. Cont. Shelf Res. 16, 753-786.

Amon, R.M.W., Benner, R., 1996a. Bacterial utilization of different size classes of dissolved organic matter. Limnol. Oceanogr. $41,41-51$.

Amon, R.M.W., Benner, R., 1996b. Photochemical and microbial consumption of dissolved organic carbon and dissolved oxygen in the Amazon River system. Geochim. Cosmochim. Acta 60, 1783-1792.

Berges, J.A., 1997. Ratios, statistics, and 'spurious' correlations. Limnol. Oceanogr. 42, 1006-1007.
Berner, R.A., 1989. Biogeochemical cycles of carbon and sulfur and their effect on atmospheric oxygen over Phanerozoic time. Palaeogeogr. Palaeochimatol. Palaeoecol. 73, 97-122.

Broecker, W.S., Peng, T.-H., 1982. Tracers in the Sea, Eldigio Press.

Canuel, E.A., Cloern, J.E., Ringelberg, D.B., Guckert, J.B., Rau, G.H., 1995. Molecular and isotopic tracers used to examine sources of organic matter and its incorporation into the food webs of San Francisco Bay. Limnol. Oceanogr. 40, 67-81.

Cauwet, G., Mackenzie, F.T., 1993. Carbon inputs and distribution in turbid rivers: the Yang Tze and Yellow rivers (China). Mar. Chem. 43, 235-246.

Cifuentes, L.A., Sharp, J.H., Fogel, M.L., 1988. Stable carbon and nitrogen isotope biogeochemistry in the Delaware estuary. Limnol. Oceanogr. 33, 1102-1115.

Devol, A.H., Hedges, J.I., in press. The biogeochemistry of the Amazon River mainstem.

Eglinton, T.I., Aluwihare, L.I., Bauer, J.E., Druffel, E.R.M., McNichol, A.P., 1996. Gas chromatographic isolation of individual compounds from complex matrices for radiocarbon dating. Anal. Chem. 68, 904-912.

Ertel, J.R., Hedges, J.I., Devol, A.H., Richey, J.E., Ribeiro, M.N.G., 1986. Dissolved humic substances of the Amazon river system. Geochim. Cosmochim. Acta 31, 739-754.

Fichez, R., Dennis, P., Fontaine, M.F., Jickells, T.D., 1993. Isotopic and biochemical composition of particulate organic matter in a shallow water estuary (Great Ouse, North Sea, England). Mar. Chem. 43, 263-276.

Fox, L.E., 1991. The transport and composition of humic substances is estuaries. In: Baker, R.A. (Ed.), Organic Substances and Sediments in Water, Vol. 1, Humics and Soils, Lewis Publishing, Chelsea, MI, 129-162.

Gibbs, R.J., 1973. Mechanisms of trace metal transport in rivers. Science 180, 71-73.

Goñi, M.A., Nelson, B., Blanchett, R.A., Hedges, J.I., 1993. Fungal degradation of wood lignins: Geochemical perspectives from $\mathrm{CuO}$-derived phenolic dimers and monomers. Geochim. Cosmochim. Acta 57, 3985-4002.

Harvey, R.H., Johnston, J.R., 1995. Lipid composition and flux of sinking and size-fractionated particles in Chesapeake Bay. Org. Geochem. 23, 751-764.

Hedges, J.I., 1988. Polymerization of humic substances in natural environments. In: Frimmel, F.H., Christman, R.F. (Eds.), Humic Substances and their Role in the Environment. Wiley, New York, 45-58.

Hedges, J.I., 1992. Global biogeochemical cycles: progress and problems. Mar. Chem. 39, 67-93.

Hedges, J.I., Keil, R.G., 1995. Sedimentary organic matter preservation: an assessment and speculative synthesis. Mar. Chem. $49,81-115$.

Hedges, J.I., Oades, J.M., 1997. Comparative organic geochemistries of soils and sediments. Org. Geochem. 27, 319361.

Hedges, J.I., Keil, R.G., Benner, R., 1997. What happens to terrestrial organic matter in the ocean?. Org. Geochem. 27, 195-212.

Hedges, J.I., Blanchette, R.A., Weliky, K., Devol, A.H., 1988. 
Effects of fungal degradation on the $\mathrm{CuO}$ oxidation products of lignin: a controlled laboratory study. Geochim. Cosmochim. Acta 52, 2717-2726.

Hedges, J.I., Cowie, G.L., Richey, J.E., Quay, P.D., 1994. Origins and processing of organic matter in the Amazon River as indicated by carbohydrates and amino acids. Limnol. Oceanogr. 39, 743-761.

Hedges, J.I., Clark, W.A., Quay, P.D., Richey, J.E., Devol, A.H., Santos, U.deM., 1986a. Compositions and fluxes of particulate organic material in the Amazon River. Limnol. Oceanogr. 31, 717-738.

Hedges, J.I., Ertel, J.R., Quay, P.D., Grootes, P.M., Richey, J.E., Devol, A.H., Farwell, G.W., Schmidt, F.W., Salati, E., 1986b. Organic carbon-14 in the Amazon River system. Science 231, 1129-1131.

Henrichs, S.M., 1995. Sedimentary organic matter preservation: an assessment and speculative synthesis-a comment. Mar. Chem. 49, 127-136.

Hunter, K.A., Liss, P.S., 1979. The surface charge of suspended particles in estuarine and coastal waters. Nature 282, 823-825.

Kaplan, D.I., Bertsch, P.M., Adriano, D.C., Miller, W.P., 1993. Soil-borne colloids as influenced by water flow and organic carbon. Environ. Sci. Technol. 27, 1193-1200.

Keil, R.G., Tsamakis, E., Fuh, C.B., Giddings, C., Hedges, J.I., 1994a. Mineralogical and textural controls on organic composition of coastal marine sediments: hydrodynamic separation using SPLITT fractionation. Geochim. Cosmochim. Acta 57, 879-893.

Keil, R.G., Montlucon, D.B., Prahl, F.G., Hedges, J.I., 1994b. Sorptive preservation of labile organic matter in marine sediments. Nature 370, 549-552.

Keil, R.G., Tsamakis, E., Giddings, J.C., Hedges, J.I., 1998. Biochemical distributions (amino acids, neutral sugars and lignin phenols) among size classes of modern marine sediments from the Washington coast. Geochim. Cosmochim. Acta 62, 1347-1364.

Keil, R.G., Mayer, L.M., Quay, P.D., Richey, J.E., Hedges, J.I., 1997a. Loss of organic matter from riverine particles in deltas. Geochim. Cosmochim. Acta 61, 1507-1511.

Keil, R.G., Tsamakis, E., Wolf, N., Hedges, J.I. and Goñi, M.A., 1997b. Relationships between organic carbon preservation and mineral surface area in Amazon Fan sediments (Holes 932A and 942A). In: Flood, R.D., Piper, D.J.W., Klaus, A., Peterson, L.C. (Eds.), Proc. ODP Sci. Results, 155. Ocean Drilling Program, College Station, TX, 531-538.

Kieber, R.J., Zhou, X., Mopper, K., 1990. Formation of carbonyl compounds from UV-induced photodegradation of humic substances in natural waters: Fate of riverine carbon in the sea. Limnol. Oceanogr. 35, 1503-1515.

Laureillard, J., Saliot, A., 1993. Biomarkers in organic matter produced in estuaries: a case study of the Krka estuary (Adriatic Sea) using the sterol marker series. Mar. Chem. 43, 247-261.

De Leeuw, J.W., Largeau, C., 1993. A review of macromolecular organic compounds that comprise living organisms and their role in kerogen, coal, and petroleum formation. In: Engle, M.H., Macko, S. (Eds.), Organic Geochemistry. Plenum, New York, 23-72.

Lichtfouse, É., Budzinski, A., $1995 .{ }^{13} \mathrm{C}$ analysis of molecular organic substances, a novel breakthrough in analytical sciences. Analysis 23, 364-369.

Ludwig, W., Probst, J.-L., Kempe, S., 1996. Predicting the oceanic input of organic carbon by continental erosion. Global Biogoechem. Cycles 10, 23-41.

Mantoura, R.F.C., Woodward, E.M.S., 1983. Conservative behaviour of riverine dissolved organic carbon in the Severn Estuary: chemical and geochemical implications. Geochim. Cosmochim. Acta 47, 1293-1309.

Mayer, L.M., 1994a. Surface area control of organic carbon accumulation in continental shelf sediments. Geochim. Cosmochim. Acta 58, 1271-1284.

Mayer, L.M., 1994b. Relationships between mineral surfaces and organic carbon concentrations in soils and sediments. Chem. Geol. 114, 247-363.

Mayer, L.M., Keil, R.G., Macko, S.A., Joye, S.B., Ruttenberg, K.C., Aller, R.C., 1998. Importance of suspended particulates in riverine delivery of bioavailable nitrogen to coastal zones. Global Biogeochem. Cycles 12, 573-580.

Meybeck, M., 1982. Carbon, nitrogen and phosphorus transport by world rivers. Am. J. Sci. 282, 401-450.

Michalopoulos, P., Aller, R.C., 1995. Rapid clay mineral formation in Amazon Delta sediments: reverse weathering and oceanic elemental cycles. Science 270, 614-617.

Middelburg, J.J., 1989. A simple rate model for organic matter degradation in marine sediments. Geochim. Cosmochim. Acta 53, 1577-1581.

Mopper, K., Zhou, X., Kieber, R.J., Kieber, D.J., Sikorski, R.J., Jones, R.D., 1991. Photochemical degradation of dissolved organic carbon and its impact on the oceanic carbon cycle. Nature 353, 60-62.

Moran, M.A., Pomeroy, L.R., Sheppard, E.S., Atkinson, L.P., Hodson, R.E., 1991. Distribution of terrestrially derived dissolved organic matter on the southeastern US continental shelf. Limnol. Oceanogr. 36, 1134-1149.

Nelson, P.N., Baldock, J.A., Oades, J.M., 1993. Concentration and composition of dissolved organic carbon in streams in relation to catchment soil properties. Biogeochemistry 19, 27-50.

Nelson, P.N., Dictor, M.-C., Soulas, G., 1994. Availability of organic carbon in soluble and particle-size fractions from a soil profile. Soil Biol. Biochem. 26, 1549-1555.

Richey, J.E., Hedges, J.I., Devol, A.H., Quay, P.D., Victoria, R., Martinelli, L., Forsberg, B.R., 1990. Biogeochemistry of carbon in the Amazon River. Limnol. Oceanogr. 35, 352-371.

Santschi, P.H., Guo, L., Baskaran, M., Trumbore, S., Southon, J., Bianchi, T.S., Honeyman, B., Cifuentes, L., 1995. Isotopic evidence for the contemporary origin of high-molecular weight organic matter in oceanic environments. Geochim. Cosmochim. Acta 59, 625-631.

Schlesinger, W.H., Melack, J.M., 1981. Transport of organic carbon in the world's rivers. Tellus 33, 172-187.

Schoell, M., Hayes, J.M., 1994. Compound-specific isotope analysis in biogeochemistry and petroleum research. Org. Geochem. 21, 561-827.

Schwarzenbach, R.P., Gschwend, P.M., Imboden, D.M., 1993. Environmental Organic Chemistry, Wiley.

Showers, W.J., Angle, D.G., 1986. Stable isotopic characterization 
of organic carbon accumulation on the Amazon continental shelf. Cont. Shelf. Res. 6, 227-244.

Skoog, A., Hall, P.O.J., Hulth, S., Paxéus, N., van der Loeff, M.R., Westerlund, S., 1996. Early diagenetic production and sediment-water exchange of fluorescent dissolved organic matter in the coastal environment. Geochim. Cosmochim. Acta 60, 3619-3629.

Smith, S.V., Mackenzie, F.T., 1987. The ocean as a net heterotrophic system: implications from the carbon biogeochemical cycle. Global Biogeochem. Cycles 1, 187-198.
Theng, B.K.G., 1979. Formation and Properties of Clay-Polymer Complexes. Elsevier.

Thimsen, C.A., Keil, R.G., 1998. Potential interactions between sedimentary dissolved organic matter and minerals surfaces. Mar. Chem. 62, 65-76.

Trumbore, S., 1993. Comparison of carbon dynamics in tropical and temperate soils using radiocarbon measurements. Global Biogeochem. Cycles 7, 275-290. 